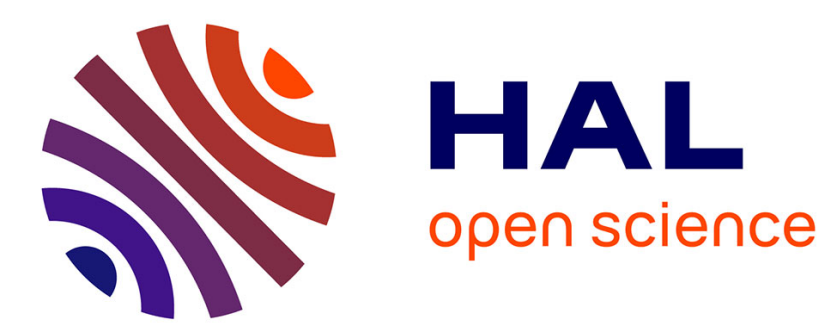

\title{
High temperature attack by SO2 of laser boronized iron
} H. Dao Duong, A. Galerie, M. Pons, M. Caillet

\section{To cite this version:}

H. Dao Duong, A. Galerie, M. Pons, M. Caillet. High temperature attack by SO2 of laser boronized iron. Journal de Physique IV Proceedings, 1993, 03 (C9), pp.C9-599-C9-606. 10.1051/jp4:1993963 . jpa-00252403

\section{HAL Id: jpa-00252403 https://hal.science/jpa-00252403}

Submitted on 1 Jan 1993

HAL is a multi-disciplinary open access archive for the deposit and dissemination of scientific research documents, whether they are published or not. The documents may come from teaching and research institutions in France or abroad, or from public or private research centers.
L'archive ouverte pluridisciplinaire HAL, est destinée au dépôt et à la diffusion de documents scientifiques de niveau recherche, publiés ou non, émanant des établissements d'enseignement et de recherche français ou étrangers, des laboratoires publics ou privés. 


\title{
High temperature attack by $\mathrm{SO}_{2}$ of laser boronized iron
}

\author{
H. Dao Duong, A. Galerie, M. Pons and M. Caillet
}

Laboratoire Science des Surfaces et Matériaux Carbonés, U.R.A. C.N.R.S. $n^{\circ} 413$, E.N.S. d'Electrochimie et d'Electrométallurgie de Grenoble, Institut National Polytechnique de Grenoble, B.P. 75, Domaine Universitaire, 38402 Saint-Martin d'Hères, France

\begin{abstract}
Laser alloying of boron predeposited on iron samples led to $\mathrm{Fe}_{-}-\mathrm{Fe}_{2} \mathrm{~B}$ alloys, with composition and microstructure depending on the irradiation conditions. Three different surface alloys were prepared corresponding to hypo-, hyper- and eutectic microstructures. This last kind of surface alloy exhibited the best behaviour in static $\mathrm{SO}_{2}$ between 400 and $600{ }^{\circ} \mathrm{C}$. The parabolic rate law, tending to a 3rd and 4th power law at the highest temperatures was explained as the result of outward iron diffusion leading to a magnetite external sublayer and inward $\mathrm{SO}_{2}$ and $\mathrm{S}_{2}$ transport, allowing the formation of a $\mathrm{FeS}-\mathrm{B}_{2} \mathrm{O}_{3}$ internal sublayer. In this sublayer, slowly reacting $\mathrm{Fe}_{2} \mathrm{~B}$ transforms to $\mathrm{B}_{2} \mathrm{O}_{3}$ leading to an increased blocking during the course of the reaction.
\end{abstract}

\section{Introduction.}

Laser alloying is a versatile way to produce surface alloys which can be used for corrosion protection. Classical techniques of boronization form generally $\mathrm{FeB}-\mathrm{Fe}_{2} \mathrm{~B}$ layers, with a high hardness, and more suitable for tribologic purposes than for corrosion protection [1,2]. This paper describes an attempt to elaborate more ductile alloys but containing sufficiently boron to afford an efficient protection against $\mathrm{SO}_{2}$ attack.

\section{Experimental.}

Iron samples were cut $(15 \times 15 \mathrm{~mm})$ in $1.5 \mathrm{~mm}$ thick iron foils with a purity of $99.5 \%$, from Goodfellow Metals Ltd. Boron powder $(\phi \sim 10 \mu \mathrm{m})$ was suspended in ethanol and sprayed onto the samples. After drying, the deposited mass was measured and fixed to $2.3 \mathrm{mg} \cdot \mathrm{cm}^{-2}$ for all the experiments.

Laser irradiation was performed with a YAG-Nd laser, guided with an optical fiber, delivering a maximum power of $350 \mathrm{~W}$ in a $1 \mathrm{~mm}$ circular spot. The samples were scanned at a $4 \mathrm{~mm} \cdot \mathrm{s}^{-1}$ speed with parallel scans and $600 \mu \mathrm{m}$ overlapping. Three different powers $(120$, $150,175 \mathrm{~W}$ ) were used, leading to power densities of $1.7,2.1$ and $2.5 \times 10^{8} \mathrm{~W} \cdot \mathrm{cm}^{-2}$.

The kinetics of corrosion were followed continuously between 400 and $600^{\circ} \mathrm{C}$ in $133 \mathrm{hPa}$ static $\mathrm{SO}_{2}$ by means of a quartz spring thermobalance. The maximum duration of the experiments was $25 \mathrm{~h}$. 


\section{Characterization of the surface alloys.}

After laser alloying, the samples were characterized by XRD, SEM, EPMA and microhardness measurements. The results on composition and microstructure are presented in table $\mathbf{I}$.

Table I. - Characterisation of the Fe-B surface alloys achieved for three different power densities (same amount of predeposited boron: $2.3 \mathrm{mg} \cdot \mathrm{cm}^{-2}$, same scanning speed: $4 \mathrm{~mm} \cdot \mathrm{s}^{-1}$ ).

\begin{tabular}{|l|c|c|c|}
\hline Power density $\mathrm{W} \cdot \mathrm{m}^{-2}$ & $1.71 \times 10^{8}$ & $2.1 \times 10^{8}$ & $2.5 \times 10^{8}$ \\
\hline Average at.\% boron in the alloy & 24 & 18 & 10 \\
\hline Phases & $\mathrm{Fe}+\mathrm{Fe}_{2} \mathrm{~B}$ & $\mathrm{Fe}+\mathrm{Fe}_{2} \mathrm{~B}$ & $\mathrm{Fe}+\mathrm{Fe}_{2} \mathrm{~B}$ \\
\hline Microstructure & hypereutectic & eutectic & hypoeutectic \\
\hline
\end{tabular}

The three compositions achieved lie in the $\mathrm{Fe}-\mathrm{Fe}_{2} \mathrm{~B}$ domain of the binary phase diagram [3]. The hypoeutectic alloy presents large iron dendrites, separated by the eutectic $\mathrm{Fe}-\mathrm{Fe}_{2} \mathrm{~B}$ material (Fig. 1). The eutectic alloy is very fine-grained and homogeneous in composition (18 at. B\%) from the external surface to the non-alloyed substrate (Fig. 2). The hypereutectic alloy presents angular $\mathrm{Fe}_{2} \mathrm{~B}$ grains (5-10 $\mu \mathrm{m}$ in size), embedded in the eutectic material (Fig. 3). The size of the $\mathrm{Fe}_{2} \mathrm{~B}$ grains diminishes when going outwards (influence of increasing solidification rate).

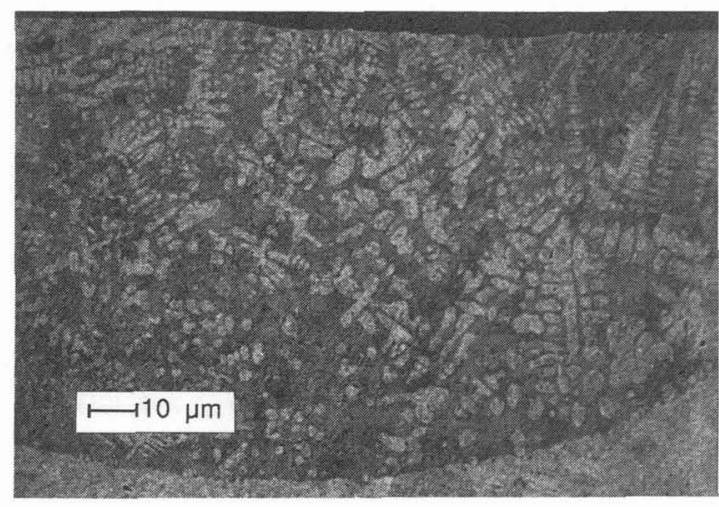

Fig. 1. - Cross-section of the $\mathrm{Fe}_{-} \mathrm{Fe}_{2} \mathrm{~B}$ hypoeutectic alloy.

Microhardness testing was performed on cross-sections in directions perpendicular to the scan axis, at different depths. The average maximum values obtained for the hypoeutectic, eutectic and hypereutectic microstructures at a depth of $20 \mu \mathrm{m}$ are 500, 850 and $950 \mathrm{HV}$. As already shown for other laser-alloyed materials [4], the microhardness was influenced by the transverse position of the measurement, as, in the geometry used (diameter of the beam: 


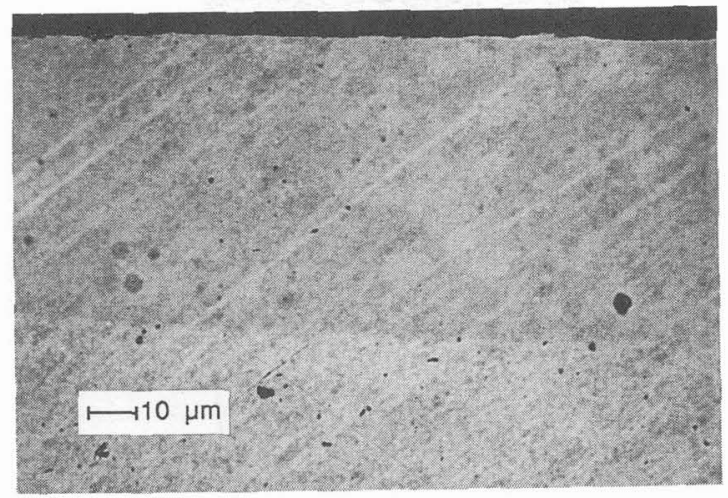

Fig. 2. - Cross-section of the $\mathrm{Fe}-\mathrm{Fe}_{2} \mathrm{~B}$ eutectic alloy.

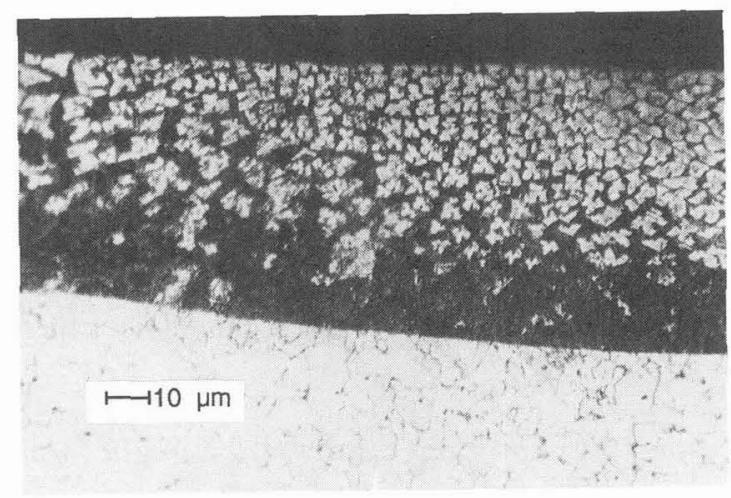

Fig. 3. - Cross-section of the $\mathrm{Fe}_{-} \mathrm{Fe}_{2} \mathrm{~B}$ hypereutectic alloy.

$1 \mathrm{~mm}$, overlapping: $600 \mu \mathrm{m}$ ), parts of the surface alloy were melted 2 or 3 times during processing. It was shown that the highest hardness was in the 2 times melted zones (Fig. 4).

\section{Corrosion of the surface alloys by $\mathrm{SO}_{2}$.}

4.1 Kinetics. - Kinetic experiments were firstly performed at 400 and $500{ }^{\circ} \mathrm{C}$ under $133 \mathrm{hPa}$ static $\mathrm{SO}_{2}$ with the three observed microstructures. All of them reduced considerably the corrosion in $\mathrm{SO}_{2}$, compared with pure iron but it was observed that hypoeutectic alloys exhibited the worse behaviour for low temperatures (Fig. 5). Eutectic and hypereutectic alloys seemed to corrode in the same manner, hypereutectic being less close to the parabolic law. This last fact appeared more evidently for higher temperatures (Fig. 6) where hypereutectic alloys corroded linearly and became the most corroded after $20 \mathrm{~h}$.

Due to their best behaviour, the eutectic alloys were more extensively studied. In particular, the influence of temperature was carefully determined. The kinetics were shown to exhibit a decreasing rate shape (Fig. 7) but could be described as parabolic at 400 and $450{ }^{\circ} \mathrm{C}$ only, 


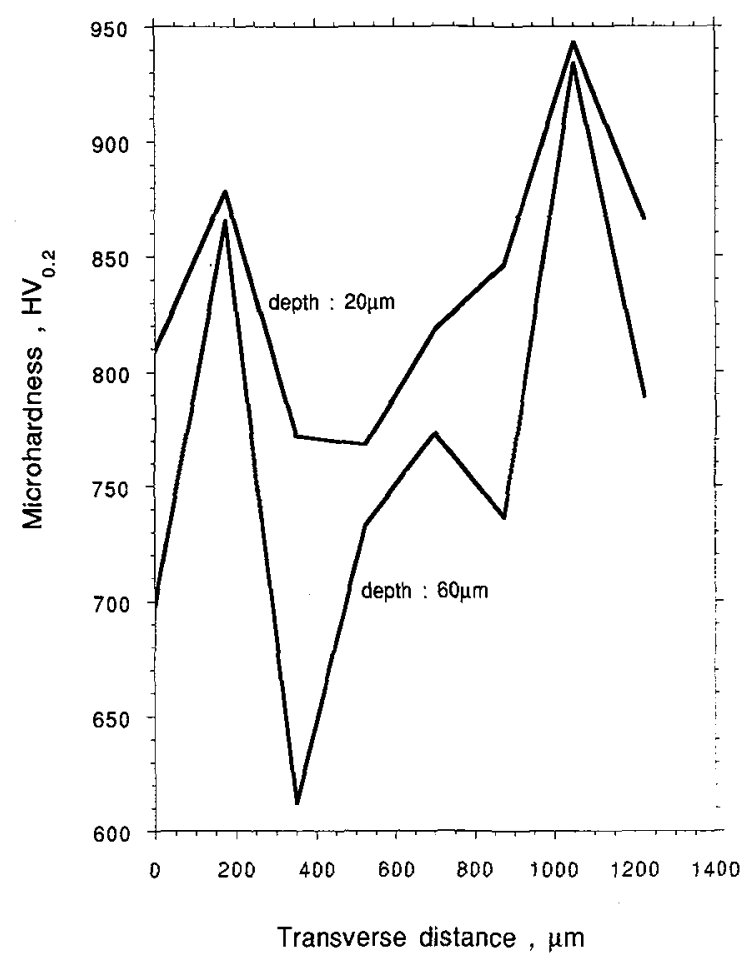

Fig. 4. - Variation of the Vickers microhardness at two depths along a direction perpendicular to the scan axis (eutectic alloy).

for durations not exceeding $10 \mathrm{~h}$. For longer times and at higher temperatures, a power law $\frac{\Delta M}{A}=k t^{n}$ fitted well the results with the exponent $n$ increasing with time (Fig. 8). At $600^{\circ} \mathrm{C}$, for example, the rate law was rapidly cubic, tending towards a 4 th power law after $20 \mathrm{~h}$ of corrosion.

4.2 FORMED PRODUCTS AND MORPHOLOGY OF THE CORROSION SCALE. - Over the entire temperature range, $\mathrm{X}$-ray diffraction experiments showed the presence of $\mathrm{Fe}_{3} \mathrm{O}_{4}$ and $\mathrm{FeS}$ in the corrosion scales. No crystallized boron-containing compound could be identified.

Microscopic examinations showed that the corrosion scale was always constituted of 2 sublayers (Fig. 9). The external one was made of large grains of $\mathrm{Fe}_{3} \mathrm{O}_{4}$, with scarce islands of $\mathrm{FeS}$. The internal one was fine-grained and showed evidence of several phases. EPMA measurements allowed to detect $\mathrm{B}$ and $\mathrm{O}$ in this layer in addition to FeS (Fig. 10).

\subsection{Discussion.}

4.3.1 Formed products. - The absence of boron in the external layer shows that this layer grows by outward iron diffusion. On the contrary, the internal layer grows inwards, including boron from the alloy. Such an observation corresponds exactly to what occurs during corrosion of low chromized steels by $\mathrm{SO}_{2}$ [5]. The presence of oxygen in this layer is in agreement with $\mathrm{SO}_{2}$ inward diffusion. This mechanism was largely discussed in the past [6, 7]. In the present experiments, it is possible that both $\mathrm{SO}_{2}$ and $\mathrm{S}$ diffused inwards, leading to the observed $\mathrm{S} / \mathrm{O}$ ratio in the internal layer near unity. 


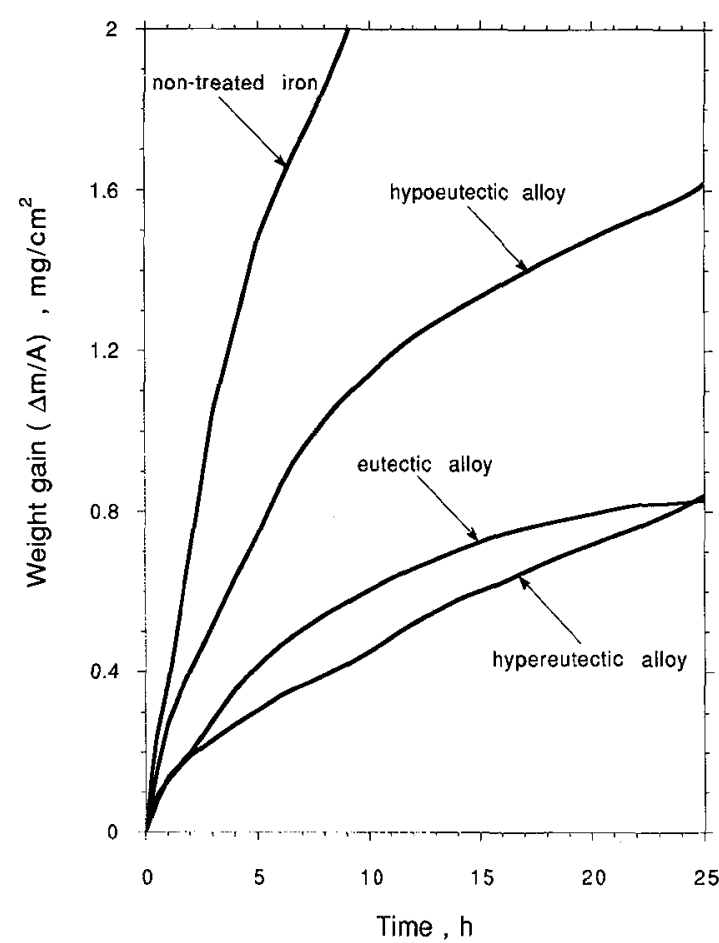

Fig. 5 .

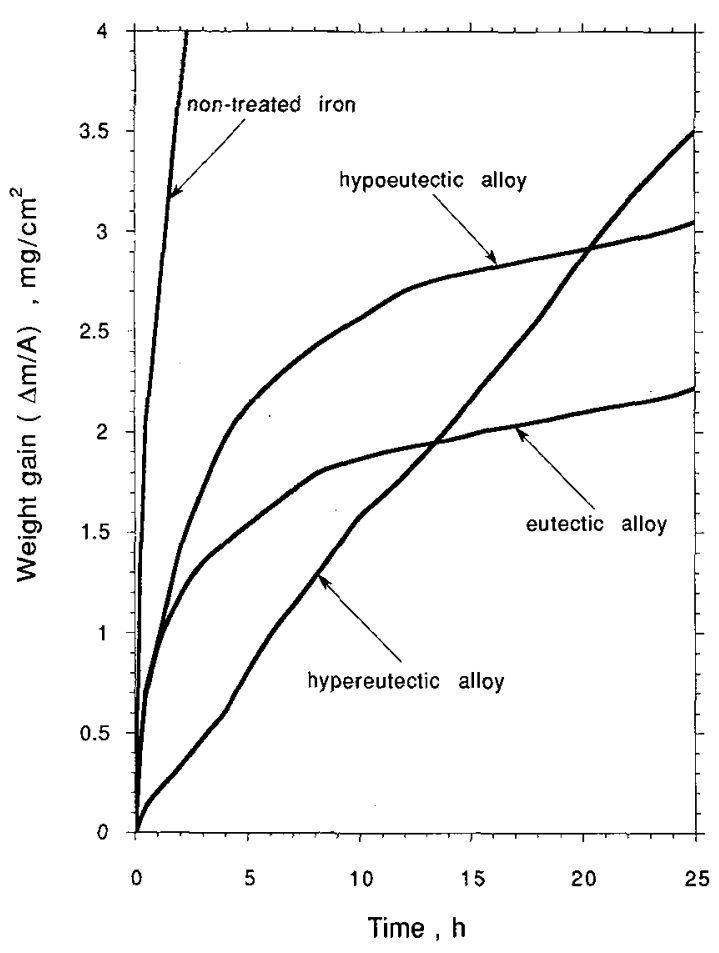

Fig. 6 .

Fig. 5. - Gravimetric curves of $\mathrm{SO}_{2}$ attack at $400{ }^{\circ} \mathrm{C}$ of the different surface alloys achieved compared to pure iron. $P_{\mathrm{SO}_{2}}=133 \mathrm{hPa}$.

Fig. 6. - Gravimetric curves of $\mathrm{SO}_{2}$ attack at $500{ }^{\circ} \mathrm{C}$ of the different surface alloys achieved. $P_{\mathrm{SO}_{2}}=$ $133 \mathrm{hPa}$.

The boron profile in this layer, opposite to that of sulfur, allows to think that $\mathrm{B}_{2} \mathrm{O}_{3}$ exists in addition to FeS. Indeed $\mathrm{B}_{2} \mathrm{O}_{3}$ and $\mathrm{FeS}$ have a large common domain in the $P_{\mathrm{S}_{2}}-P_{\mathrm{O}_{2}}$ stability diagram for the temperature range explored.

In addition to $\mathrm{FeS}$ and $\mathrm{B}_{2} \mathrm{O}_{3}$, unreacted $\mathrm{Fe}_{2} \mathrm{~B}$ is also present in the internal sublayer.

4.3.2 Kinetics. - The general decreasing rate shape observed results from limiting solid state diffusion (although $\mathrm{SO}_{2}$ slow decomposition should participate also, leading to non equilibrium $\mathrm{Fe}_{3} \mathrm{O}_{4}$ at the scale gas interface).

Compared to corrosion of pure iron, the presence of boron reduces markedly the iron diffusion through FeS. This fact is in contradiction with Wagner-Hauffe rules for vacancy diffusion, but the results of Chatterjee and Dowell [8] suggest predominent grain boundary diffusion under $700{ }^{\circ} \mathrm{C}$ (2 slopes Arrhenius' law). Sulfur and $\mathrm{SO}_{2}$ diffusion along the grain boundaries of the FeS- $\mathrm{B}_{2} \mathrm{O}_{3}$ layer is not affected by boron. This layer is therefore thicker in the presence of boron compared to what observed for pure iron $[9,10]$.

At the metal-scale interface, the iron grains of the alloy are rapidly converted to FeS, whereas $\mathrm{Fe}_{2} \mathrm{~B}$ grains are slowly superficially transformed into $\mathrm{B}_{2} \mathrm{O}_{3}$. This fact was more easily detected on hypoeutectic alloys where large Fe areas exist (Fig. 11). $\mathrm{B}_{2} \mathrm{O}_{3}$ growing within previously formed FeS is probably responsible for the deviation from the parabolic law, as the 


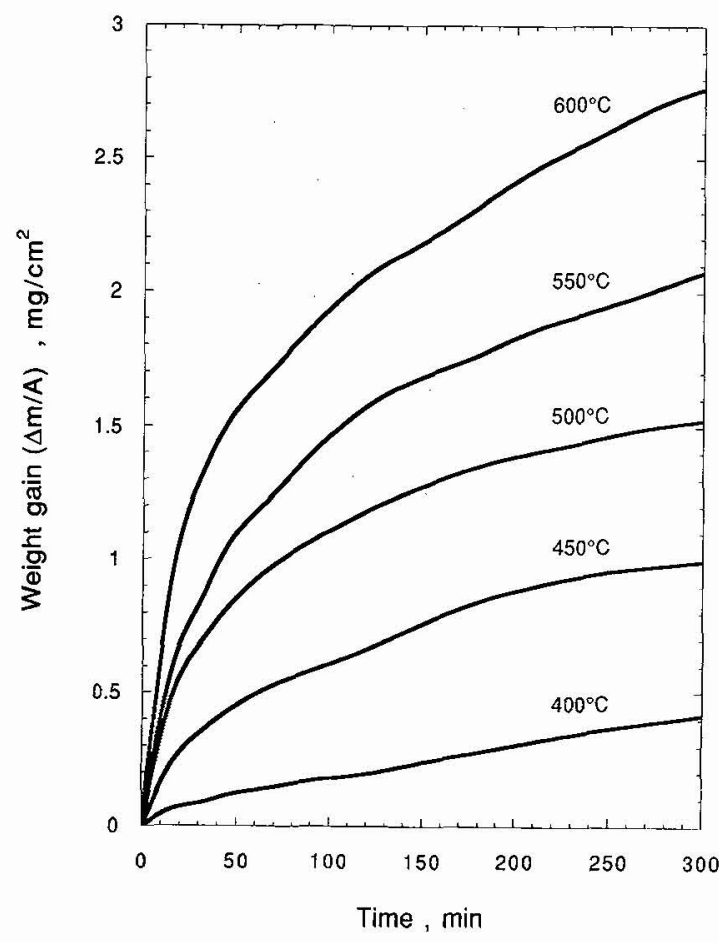

Fig. 7.

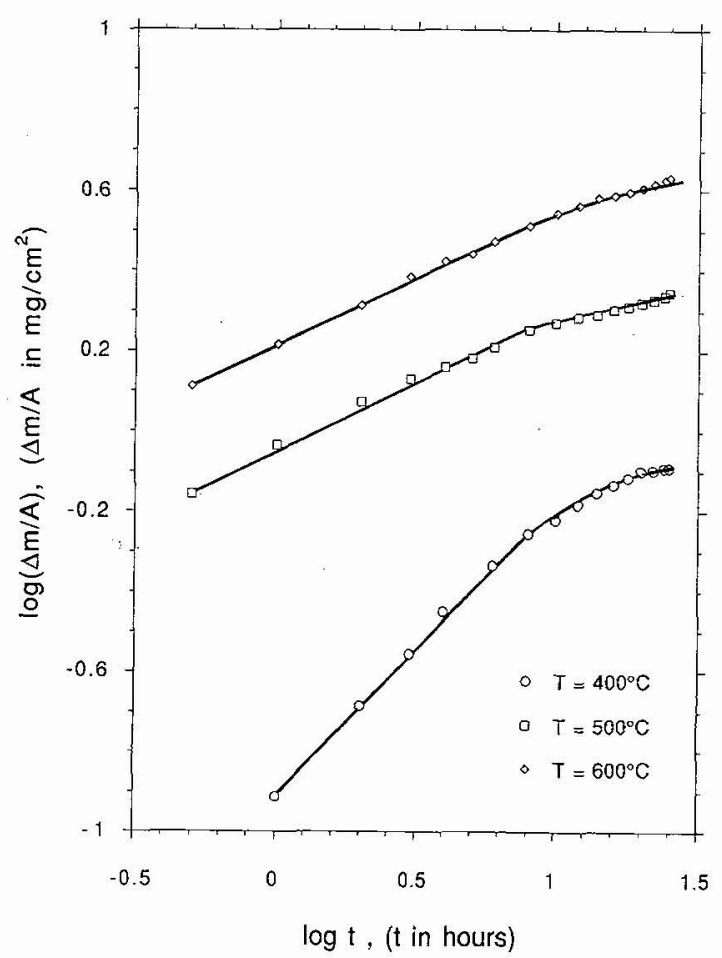

Fig. 8.

Fig. 7. - Influence on temperature on the corrosion of the eutectic surface alloy. $P_{\mathrm{SO}_{2}}=133 \mathrm{hPa}$. Fig. 8. - Log-log plot of the gravimetric curves of corrosion of the eutectic surface alloy showing the deviation from the parabolic law at high temperatures. $P_{\mathrm{SO}_{2}}=133 \mathrm{hPa}$.

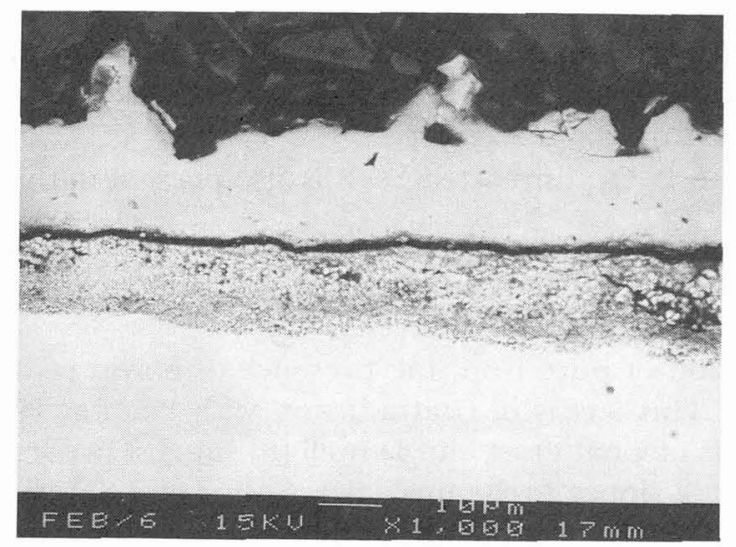

Fig. 9. - Cross-section of the scale formed by $\mathrm{SO}_{2}$ attack of the eutectic surface alloy. $P_{\mathrm{SO}_{2}}=133 \mathrm{hPa}$, $T=600^{\circ} \mathrm{C}, t=25 \mathrm{~h}$. 

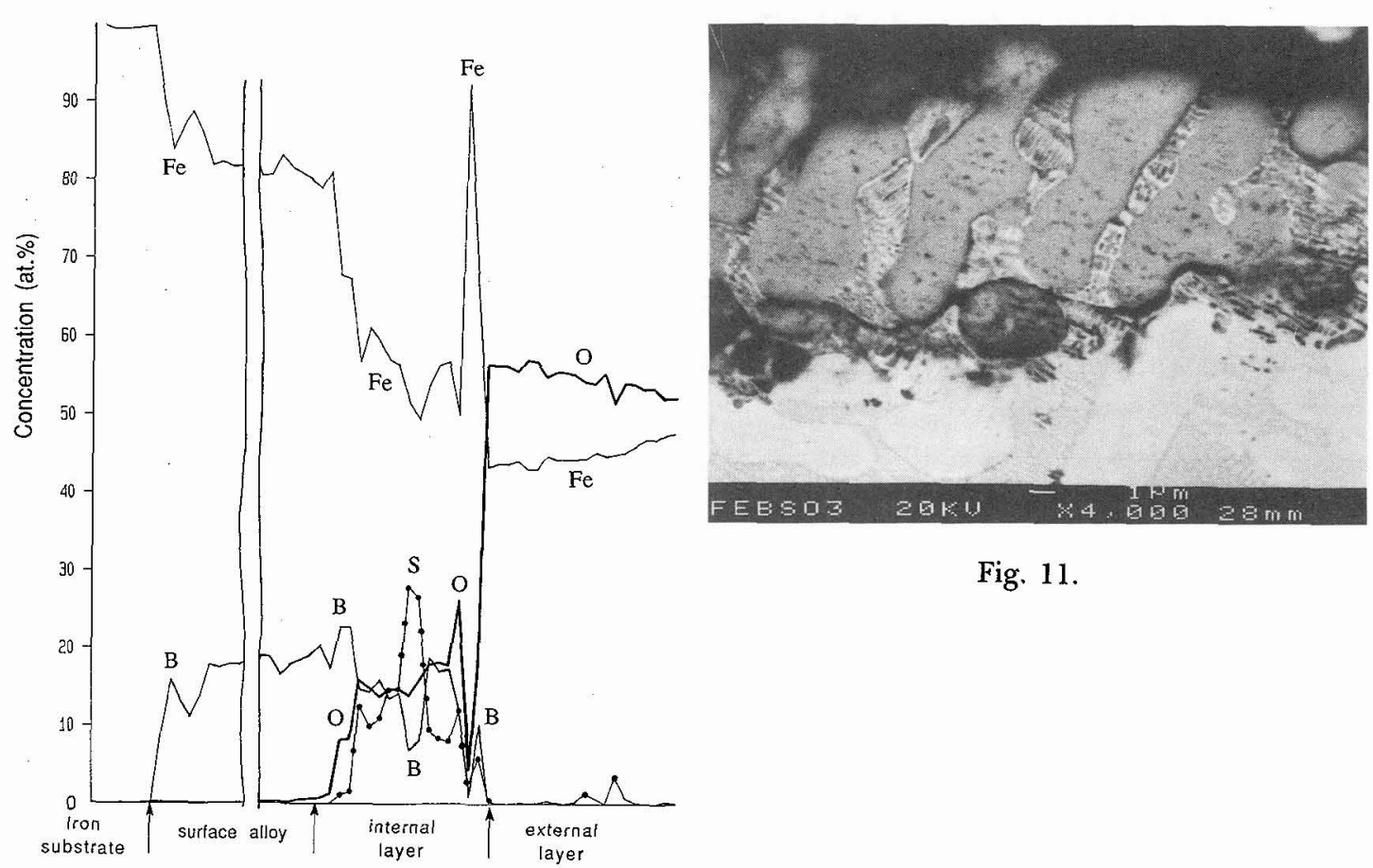

Fig. 11.

Fig. 10.

Fig. 10. - Electron probe microanalysis profiles through the corrosion scale of figure 9 .

Fig. 11. - Cross-section of the internal part of the scale formed by $\mathrm{SO}_{2}$ attack of the hypoeutectic surface alloy, showing preferential sulfidation of iron grains. $P_{\mathrm{SO}_{2}}=133 \mathrm{hPa}, T=400^{\circ} \mathrm{C}, t=25 \mathrm{~h}$.

diffusion area decreases during the course of the reaction. This influence is more sensible when $\mathrm{B}_{2} \mathrm{O}_{3}$ formation is rapid, i.e. at high temperatures, as experimentally observed.

\section{Conclusion.}

Laser alloying of boron into pure iron could be optimized to achieve homogeneous eutectic surface alloys, with a good hardness-brittleness ratio. These alloys exhibited parabolic or higher power rate laws of corrosion by $\mathrm{SO}_{2}$, leading to the formation of a duplex scale containing $\mathrm{Fe}_{3} \mathrm{O}_{4}$ in its external part and $\mathrm{FeS}$ in its internal part. In this part, $\mathrm{B}_{2} \mathrm{O}_{3}$ growing from unsulfidized $\mathrm{Fe}_{2} \mathrm{~B}$ grains is thought to account for the deviations observed from the parabolic law.

\section{References}

[1] GhatterjeE-FIScher R., Surface Modification Technologies, T.S. Sudarshan Ed. (Marcel Dekker Inc., 1989) pp. 567-609.

[2] Nguyen van T., Galerie A., Caillet M., Mater. Sci. Eng. A 121 (1989) 427-432. 
[3] MASSALSki T.B., Binary Alloy Phase Diagrams, ASM Intern., Vol. $1,2^{\text {nd }}$ Edition (The Materials Information Society, 1990).

[4] Fishman M., Zahavi J., ZEVIN L.S., J. Mater. Res. 3 (6) (1988) 1108-1118.

[5] Skalli A., Galerie A., Caillet M., Mater. Sci. Eng. 87 (1987) 175-182.

[6] Birks N., Proc. 25ème Réunion Intern. Cinétique des Réactions dans les Systèmes Chimiques Hétérogènes, 30,1 - 30,10. (Société de Chimie-Physique, Dijon, 1974).

[7] Gesmundo F., Young D.J., Roy S.K., High Temp. Mater. Proces. 8 (1989) 149-190.

[8] ChatterjeE B., Dowel A.J., Corros. Sci. 15 (1975) 639-647.

[9] FLATLEY T., BiRKS N., J.I.S.I. 209 (1971) 523-533.

[10] GileWiCZ-WOLTER J., Oxid. Met. 11 (1977) 81-90. 